\title{
KETERSEDIAAN KOLEKSI TERCETAK DALAM MEMENUHI KEPUASAN PENGGUNA PADA PERPUSTAKAAN ITB
}

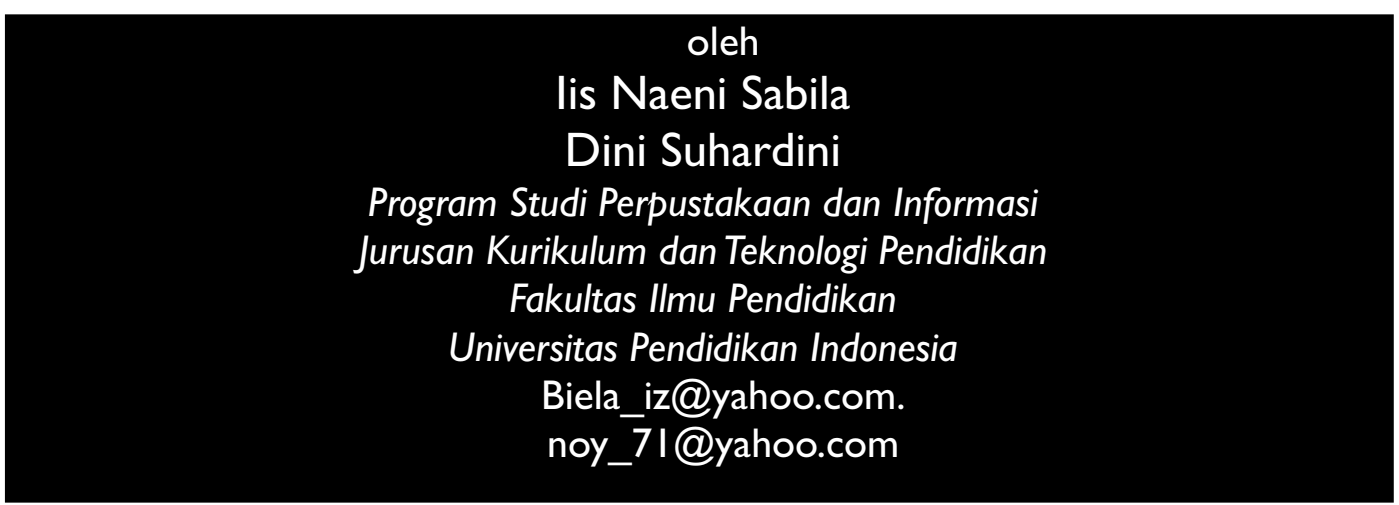

\begin{abstract}
ABSTRAK
Penelitian ini dilatar belakangi oleh koleksi tercetak yang merupakan salah satu modal bagi perpustakaan dalam memenuhi kebutuhan pengguna sehingga tercipta rasa puas. Dalam hal ini bagaimana ketersediaan koleksi tercetak dalam memenuhi kepuasan pengguna pada Perpustakaan ITB?. Tujuan penelitian untuk memperoleh gambaran tentang ketersediaan koleksi tercetak dalam memenuhi kepuasan pengguna pada Perpustakaan ITB, memperoleh gambaran tentang kelengkapan koleksi tercetak, kerelevanan koleksi tercetak dan kemutakhiran koleksi tercetak dalam memenuhi kepuasan pengguna pada Perpustakaan ITB. Penelitian ini menggunakan metode deskriptif dengan pendekatan kuantitatif. Teknik pengumpulan data dilakukan dengan angket/kuesioner. Hasil dari penelitian ini adalah bahwa ketersediaan koleksi tercetak telah memenuhi kepuasan pengguna, koleksi tercetak yang tersedia di perpustakaan ITB lengkap, relevan dan mutakhir sehingga pengguna merasa puas. Implikasi dari penelitian bahwa untuk mengoptimalkan ketersediaan koleksi tercetak Perpustakaan ITB harus selalu berorientasi kepada kebutuhan pengguna.
\end{abstract}

Kata Kunci. Ketersediaan Koleksi Tercetak, Kepuasan, Pengguna 


\section{PENDAHULUAN}

Perpustakaan seperti yang sudah kita ketahui adalah sebagai jantung sebuah perguruan tinggi, perpustakaan perguruan tinggi yang didalamnya terdapat berbagai macam informasi untuk mengembangkan berbagai macam ilmu dan harus mampu mendukung segala kebutuhan informasi, informasi itu termuat dalam sebuah koleksi yang merupakan salah satu komponen terpenting dalam perpustakaan. Koleksi pada dasarnya ada dua bentuk yaitu koleksi tercetak dan non cetak, dalam penelitian ini penulis memilih koleksi tercetak karena koleksi tercetak masih banyak diminati oleh para pengguna, walaupun sekarang sudah era digital namun bentuk fisik sebuah informasi masih banyak digunakan oleh para pengguna. Kebutuhan pengguna yang beragam menyebabkan aktifitas semakin meningkat dalam memenuhi informasi, pengguna yang tidak memiliki waktu banyak dalam menemukan informasi yang tepat, akurat, dan sesuai kebutuhan pengguna serta selalu haus akan informasi sebagai kebutuhan informasinya yang berdampak pada sebuah harapan yang harus terpennuhi dalam mendapatkan informasi, harapan pengguna yang diyakini mempunyai peranan dalam menentukan kualitas koleksi tercetak dalam memenuhi kepuasan pengguna.

\section{Identifikasi}

1. Pengguna sering kebingungan dalam mencari informasi dibutuhkannya dalam koleksi tercetak yang tersedia di perpustakaan.

2. Pengguna sering mendapatkan kesulitan dalam menemukan informasi yang sesuai dengan program studinya.

3. Pengguna sering mendapatkan ketidaktepatan is i bahan pustaka/koleksi tercetak dengan informasi yang dibutuhkannya.
4. Kesetian pengguna terhadap perpustaaan masih diragukan.

\section{Rumusan Masalah}

Rumusan masalah secara umum bagaimana ketersediaan koleksi tercetak dalam memenuhi kepuasan pengguna pada Perpustakaan ITB?

Rumusan masalah khususnya yaitu

1. Bagaimana kelengkapan koleksi tercetak dalam memenuhi kepuasan pengguna pada Perpustakaan ITB?

2 Bagaimana kerelevanan/kesesuaian koleksi tercetak dalam memenuhi kepuasan pengguna pada Perpustakaan ITB?

3 Bagaimana kemutakhiran koleksi tercetak dalam memenuhi kepuasan pengguna pada Perpustakaan ITB?

\section{Tujuan}

Secara umum tujuannya adalah untuk memperoleh gambaran tentang ketersediaan koleksi tercetak dalam memenuhi kepuasan pengguna di Perpustakaan ITB

Secara khusus tujuannya adalah

1. Untuk memperoleh gambaran tentang kelengkapan koleksi tercetak dalam memenuhi kepuasan pengguna pada Perpustakaan ITB.

2. Untuk memperoleh gambaran tentang kerelevanan/kesesuaiaan koleksi tercetak dalam memenuhi kepuasan pengguna pada Perpustakaan ITB.

3. Untuk memperoleh gambaran tentang kemutakhiran koleksi tercetak dalam memenuhi kepuasan pengguna pada Perpustakaan ITB

\section{Manfaat}

Secara teoritis penelitian ini bermanfaat dalam mengembangkan pengetahuan dan pengalaman di bidang perpustakaan khususnya dibidang pengembangan koleksi tercetak dengan memperhatikan indikator, kelengkapan, kerelevanan dan kemutakhiran. 
Secara praktis manfaat bagi Pustakawan yaitu memberikan masukan kepada pustakawan untuk mengembangkan koleksinya sesuai kebutuhan pengguna dan bagi pengguna yaitu mendapatkan kepuasan terhadap koleksi tercetak yang tersedia di Perpustakaan ITB sehingga pengguna selalu datang ke perpustakaan.

\section{PEMBAHASAN}

Ketersediaan berasal dari kata dasar sedia, yang berarti menyediakan atau mengadakan sesuatu. Menurut Kamus Besar Bahasa Indonesia, ketersediaan adalah kesiapan suatu sarana (tenaga, barang, modal, anggaran ) untuk dapat digunakan untuk dioperasikan dalam waktu yang telah ditentukan (Kamus Besar Bahasa Indonesia, 1999: 888). Dari pengertian tersebut dapat dikemukakan ketesedian koleksi adalah segala sesuatu yang diadakan berupa bahan pustaka yang akan digunakan dalam waktu yang telah dipersiapkan.

Dengan tersedianya koleksi yang dibutuhkan pengguna diharapakan melahirkan kepuasan bagi para pengguna perpustakaan. Kepuasan adalah merupakan salah satu barometer keberhasilan penyelenggaraan suatu jasa layananan seperti halnya layanan perpustakaan maupun layanan jasa infornasi lainnya.

Berbagai koleksi yang terdapat di perpustakaan perguruan tinggi umumnya disesuaikan dengan kebutuhan pengguna yakni kalangan mahasiswa dan pengajar. dalam mewujudkan perpustakaan perguruan tinggi sebagai pusat sumber informasi yang dapat menunjang kelancaran belajar mahasiswa maka segala informasi dari bebagai media cetak yang mendukung lembaga itu, selalu diupayakan pengadaanya untuk kemudian diolah dan disebarluaskan di lingkungan perguruan tinggi yang bersangkutan.

Penyediaan informasi yang mendalam tentang ilmu pengetahuan pada perpusta- kaan perguruan tinggi merupakan salah satu misi yang diemban oleh perpustakaan perguruan tinggi, disamping misi-misi lainnya baik edukatif, komunikatif, maupun penelitian. Hal ini merupakan tugas perpustakaan perguruan tinggi untuk melaksanakan Tri Dharma Perguruan tinggi.

Dalam dunia perpustakaan dilakukan pengelompokan terhadap sumbersumber informasi agar para pengguna perpustakaan dapat menemukan informasi yang sesuai dengan kebutuhannya secara cepat. Untuk itu para pengguna perpustakaan perlu memahami dan mengenal segala sumber informasi yang tersedia di perpustakaan. Koleksi bahan pustaka yang tersedia di perpustakaan perguruan tingg menurut Soeatminah (2000: 40) seyogyanya:

"buku referensi, buku teks baik yang diperlukan oleh mahasiswa maupun dosen, baik yang diwajibkan untuk mata-kuliah tertentu, maupun yang dianjurkan, buku untuk pengembangan ilmu yang melengkapi dan memperkaya pengetahuan diluar bidang studi yang ditekuni, penerbitan perguruan tinggi, baik penerbitan sendiri maupun penerbitan perguruan tinggi lain, penerbitan pemerintah, terutama produk hukum yang berkaitan dengan perguruan tinggi, laporanlaporan, terutama dari lembaganya sendiri, skripsi, tesis, disertasi, terutama dari lembaganya sendiri”.

Keberhasilan perpustakaan sering diukur dari keberhasilan dalam memberikan layanan dalam hal ini menyediakan koleksi tercetak kepada para pengguna perpustakaan. Penyediaan koleksi tercetak ini harus lengkap, relevan, dan mutakhir untuk mendukung keberhasilan perpustakaan dalam membe- 
rikan kepuasan kepada pengguna.

Kepuasan pengguna merupakan suatu efek yang muncul dari diri pengguna setelah menggunakan koleksi yang ada di perpustakaan. Ketersediaan koleksi yang ada di perpustakaan dilihat dari sebagai berikut:

Kelengkapan, koleksi perpustakaan hendaknya lengkap dalam arti terkait dengan kebutuhan pengguna utama perpustakaan walaupun secara hakiki

1. Sudah diketahui bahwa tidak mungkin bagi semua perpustakaan dapat memenuhi semua kebutuhan penggunanya. Namun demikian, penting bagi pustakawan untuk dapat mendeteksi kebutuhan seharihari dari pengguna utama perpustakaannya sehingga dapat menajdi perpustakaan andalan para pengguna. Tentunya wajar sebuah perpustakaan akan ditinggalkan oleh penggunanya apabila apa yang dicari pengguna sering tidak bisa diperoleh di perpustaaan itu.

2. Relevansi, koleksi perpustakaan hendaknya relevan dengan aktivitas yang telah diprogramkan oleh perpustakaan s e h ing ga memudahkan pencapaian kinerja perpustakaan yang memuaskan para stakeholders.

Kemutakhiran atau up to date, koleksi hendaknya mengikuti perkembangan ilmu pengetahuan dan teknologi mutakhir. Dengan demikian, perpustakaan harus mengadakan dan memperbaharui bahan pustaka yang menjadi koleksi.(Yuyu, yulia dan Janti Gritinawati Sujana, 2009:24).

\section{Pengguna}

Pengguna merupakan salah satu unsur penting dalam kemajuan perpustakaan. Untuk memenuhi kebutuhan pengguna, perpustakaan harus mampu mengenal dan mengidentifikasi kebutuhan informasi pengguna serta mengusahakan memenuhi informasi penggunanya. Pengguna menurut (Sulistyo-Basuki, 1992: 201) dikategorikan menjadi tiga jenis pengguna:

1. Pengguna yang belum terlibat dalam kehidupan aktif seperti mahasiswa

2. Pengguna yang mempunyai pekerjaan, informasi yang diinginkan merupakan informasi yang berkaitan dengan pekerjaan mereka. Kelompok ini digolongkan berdasarkan aktivitas utama (manajemen, riset, pengembangan, produksi, jasa), berdasarkan cabang aktivitas dan jasa/atau bidang spesialis (pegawai negeri, pertanian, industri) dan berdasarkan tingkat pendidikan tanggung jawab (profesional. Teknisi, asisten, administrasi)

3. Pengguna umum yang memerlukan informasi umum untuk keperluan khusus.

\section{Kepuasan}

Mengenai pengertian kepuasan itu sendiri dapat diartikan sebagai situasi, keadaan atau kondisi dimana seseorang atau kelompok orang telah mendapatkan apa yang dibutuhkan atau diinginkannya. Jadi kepuasan pengguna informasi adalah merupakan tingkat kesepadanan antara kebutuhan pengguna terhadap informasi yang diinginkan dengan kenyataan yang diterima. Menurut Supranto (2011: 1),“...suatu dikatakan puas, jika apa yang diterima melebihi atau sama dengan dari yang diharapkan, sebaliknya suatu dikatakan tidak puas, jika apa yang diterima kurang dari yang diharapkan."

Kebutuhan informasi pengguna harus mampu dipenuhi oleh perpustakaan. Menurut Katz dan Haz (Yusup, 1995: 3-4) mengemukakan pendapatnya mengenai pendekatan akan kebutuhan informasi seseorang sebagai berikut:

1. Kebutuhan kognitif. Kebutuhan ini berkaitan erat dengan kebutuhan untuk memperkuat atau menambah 
informasi, pengetahuan, dan pemahaman seseorang akan lingkungannya.

2. Kebutuhan afektif. Kebutuhan ini dikaitkan dengan penguatan estetis, hal yang dapat menyenangkan, dan pengalaman-pengalaman emosional.

3. Kebutuhan integrasi personal. Kebutuhan ini sering dikaitkan dengan penguatan kredibilitas, kepercayaan, stabilitas, dan status individu yang berasal dari hasrat seseorang untuk mencari harga diri.

4.. Kebutuhan integrasi sosial. Kebutuhan ini dikaitkan dengan penguatan hubungan dengan keluarga, teman dan orang lain di dunia.

5. Kebutuhan berkhayal. Kebutuhan ini dikaitkan dengan kebutuhankebutuhan untuk melahirkan diri, melepskan ketegangan, dan hasrat untuk mencari hiburan atau pengalihan.

Setiap perpustakaan harus memperhatikan kebutuhan pengguna. Pemenuhan kebutuhan pengguna akan meningkatkan kepuasan pengguna di perpustakaan sehingga memberikan manfaat bagi perpustakaan. Menurut Tjiptono (2008: 24) terdapat beberapa manfaat yang diperoleh atas kepuasan pengguna:

1. Hubungan antara perpustakaan dan penggunanya menjadi harmonis

2. Memberikan citra yang baik bagi perpustakaan

3. Mendorong terciptanya loyalitas pengguna

4. Mendorong pengguna untuk kembali menggunakan jasa perpustakaan
Agar informasi yang disediakan di perpustakaan dimanfaatkan oleh pengguna, maka perpustakaan harus memperhatikan kebutuhan dan tuntutan pengguna perpustakaan agar pengguna merasa puas.

Menurut Supranto (2011: 2), “...orang cenderung berusaha memenuhi kebutuhan yang lebih rendah sebelum memenuhi kebutuhan yang lebih tinggi. Bila suatu kebutuhan telah terpenuhi maka daya motivasinya akan berhenti". Dapat dikatakan bahwa semakin rendah tingkat kebutuhan seseorang maka semakin tinggi kepuasan dapat terpenuhi, sebaliknya semakin tinggi tingkat kebutuhan maka semakin rendah tingkat kepuasan terpenuhi.

bahwa:

Sulistyo Basuki menjelaskan

"Untuk memenuhi kebutuhan cultural dan informasi pemakai maka perpustakaan harus mampu mengenali kebutuhan pemakai, mengusahakan tersedianya jasa pada waktu diperlukan, serta mendorong pemakai menggunakan perpustakaan" (Sulistyo , 1993: 128)

Terpenuhinya kebutuhan informasi pengguna akan menimbulkan perasaan puas, senang. Kepuasan akan nampak dalam sikap dan prilaku pengguna terhadap perpustakaan. Perilaku pengguna yang merasa puas dengan koleksi yang ada di perpustakaan, maka mereka akan kembali datang memanfaatkan koleksi perpustakaan dan mereka akan mempromosikan kepada orang lain tentang perpustakaan.

\section{METODE}

Metode yang digunakan adalah metode deskriptif dengan pendekatan kuantitatif. Menurut Nawawi (2001: 63) "metode deskriptif dapat diartikan sebagai prosedur pemecahan masalah yang diselidiki dengan menggambarkan sub- 
yek/obyek penelitian pada saat sekarang berdasarkan fakta-fakta yang tampak atau sebagaimana adanya. Pendekatan kuantitatif menurut Sugiyono (2012: 8) "penelitian yang digunakan untuk populasi atau sampel tertentu, pengumpulan data menggunakan instrumen penelitian, analsisi data bersifat kuantitatif/statistik". Skala dalam penelitian ini menggunakan Skala Likert dan Untuk pengolahan Dn pwnafsiran datanya menggunakan rumus Supardi.

Populasi yang digunakan dalam penelitian ini adalah 24.240 pengguna pada bulan februari 2013 dengan menggunakan teknik accidental sampling. Menurut Nawawi (2001: 156) "Accidental sampling adalah teknik yang dalam pengambilan sampelnya tidak ditetapkan lebih dahulu namun langsung mengumpulkan data dari unit sampling yang ditemuinya, setelah jumlahnya mencukupi pengumpulan datanya dihentikan."

\section{Deskriptif Perindikator}

Untuk memudahkan penulis mengambil kesimpulan untuk indikator kelengkapan koleksi tercetak, maka dalam penelitian ini indikator kelengkapan koleksi tercetak diklasifikasikan kedalam beberapa kategori, yaitu:

- Sangat Setuju(SS)

- Sangat Baik (SB)

- Setuju(S)

- Baik (B)

- Ragu-Ragu(RR)

- Cukup (C)

- Tidak Setuju(TS)

- Kurang (K)

- Sangat Tidak Setuju (STS)

- Sangat Kurang (SK).
Tabel. 1.1

Kelengkapan koleksi tercetak dalam memenuhi kepuasan pengguna

\begin{tabular}{|c|l|l|l|l|l|l|}
\hline Pernyataan & \multicolumn{5}{|c|}{ Alternatif jawaban } & $\begin{array}{l}\text { Skor } \\
\text { total }\end{array}$ \\
\hline & SS & S & R & TS & STS & \\
\hline $\mathbf{1}$ & 33 & 58 & 9 & & & 415 \\
\hline $\mathbf{2}$ & 14 & 62 & 18 & 6 & & 380 \\
\hline $\mathbf{3}$ & 6 & 37 & 30 & 26 & 1 & 321 \\
\hline $\mathbf{4}$ & 7 & 44 & 37 & 11 & 1 & 345 \\
\hline $\mathbf{5}$ & 4 & 40 & 31 & 23 & 2 & 321 \\
\hline $\mathbf{6}$ & 7 & 39 & 26 & 23 & 5 & 300 \\
\hline $\mathbf{7}$ & 11 & 43 & 42 & 4 & & 361 \\
\hline $\mathbf{8}$ & 10 & 57 & 20 & 13 & & 364 \\
\hline Total & 92 & 380 & 213 & 106 & 9 & 2807 \\
\hline
\end{tabular}

Tabel. 1.2.

Kerelevanan koleksi tercetak dalam memenuhi kepuasan pengguna

\begin{tabular}{|c|c|l|l|l|l|r|}
\hline \multirow{2}{*}{ Pernyataan } & \multicolumn{5}{|c|}{ Alternatif jawaban } & $\begin{array}{l}\text { Skor } \\
\text { total }\end{array}$ \\
\hline & SS & S & R & TS & STS & \\
\hline $\mathbf{9}$ & 11 & 53 & 31 & 5 & & 370 \\
\hline $\mathbf{1 0}$ & 11 & 69 & 14 & 6 & & 385 \\
\hline $\mathbf{1 1}$ & 13 & 42 & 33 & 10 & 2 & 354 \\
\hline $\mathbf{1 2}$ & 14 & 51 & 29 & 5 & 1 & 372 \\
\hline $\mathbf{1 3}$ & 22 & 56 & 18 & 4 & - & 396 \\
\hline $\mathbf{1 4}$ & 8 & 50 & 33 & 2 & - & 233 \\
\hline $\mathbf{1 5}$ & 24 & 45 & 29 & 2 & - & 391 \\
\hline Total & 103 & 366 & 187 & 34 & 3 & 2501 \\
\hline
\end{tabular}


Tabel. 1.3.

kemutakhiran koleksi tercetak dalam memenuhi kepuasan pengguna

\begin{tabular}{|c|c|l|l|l|l|l|}
\hline Pernyataan & \multicolumn{5}{|c|}{ Alternatif jawaban } & $\begin{array}{l}\text { Skor } \\
\text { total }\end{array}$ \\
\hline & SS & S & R & TS & STS & \\
\hline $\mathbf{1 6}$ & 14 & 49 & 33 & 4 & - & 373 \\
\hline $\mathbf{1 7}$ & 7 & 47 & 32 & 14 & - & 347 \\
\hline $\mathbf{1 8}$ & 5 & 52 & 36 & 6 & 1 & 343 \\
\hline $\mathbf{1 9}$ & 7 & 46 & 41 & 6 & - & 355 \\
\hline $\mathbf{2 0}$ & 27 & 50 & 22 & 1 & - & 403 \\
\hline Total & 60 & 244 & 164 & 31 & 1 & 1821 \\
\hline
\end{tabular}

Tabel. 1.4

Ketersediaan koleksi tercetak dalam memenuhi kepuasan pengguna

\begin{tabular}{|c|l|l|l|l|l|l|}
\hline Pernyataan & \multicolumn{5}{|c|}{ Alternatif jawaban } & $\begin{array}{l}\text { Skor } \\
\text { total }\end{array}$ \\
\hline & SS & S & R & TS & STS & \\
\hline $\mathbf{2 1}$ & 6 & 42 & 39 & 13 & - & 315 \\
\hline $\mathbf{2 2}$ & 10 & 54 & 24 & 11 & 1 & 361 \\
\hline $\mathbf{2 3}$ & 16 & 60 & 20 & 4 & - & 388 \\
\hline $\mathbf{2 4}$ & 15 & 53 & 19 & 5 & 2 & 356 \\
\hline $\mathbf{2 5}$ & 19 & 41 & 26 & 13 & 1 & 364 \\
\hline $\mathbf{2 6}$ & 24 & 52 & 19 & 5 & - & 395 \\
\hline Total & 90 & 302 & 147 & 51 & 4 & 2179 \\
\hline
\end{tabular}

Berdasarkan deskripsi data hasil penelitian yang bersumber dari data hasil penelitian dapat diketahui bahwa ketersediaan koleksi tercetak dalam memenuhi kepuasan pengguna berada dalam kategori baik, untuk lebih jelasnya lagi, pembahasannya akan dipaparkan dibawah ini:

1. Kelengkapan koleksi tercetak pada Perpustakaan ITB

Kelengkapan koleksi tercetak dalam memenuhi kepuasan pengguna berkategori baik hal ini karena diantara- nya pengguna setuju Perpustakaan ITB menyediakan berbagai jenis koleksi tercetak, koleksi buku-buku yang lengkap dan mendalam, jumlah koleksi tercetak yang tersedia sudah memenuhi kebutuhan penggunanya, dan setuju Perpustakaan ITB menyediakan koleksi tercetak yang spesifik tentang suatu ilmu pengetahuan. Menurut Soeatminah (2000: 40) koleksi perpustakaan perguruan tinggi seyogyanya yaitu "... buku referensi, buku teks, buku pengembangan, penerbitan perguruan tinggi, penerbitan pemerintah, laporan, skripsi, tesis, disertasi"

Sesuai dengan fungsi perpustakaan secara umum yaitu sebagai fungsi pendidikan, fungsi penelitian, fungsi informatif, dan rekreatif tentunya Perpustakaan ITB harus ditunjang dengan koleksi tercetak yang lengkap untuk mencapai fungsi tersebut, maka dari itu pihak perpustakaan perlu memeperhatikan kembali koleksi-koleksi yang tersedia di perpustakaan.

"Bahan pustaka diupayakan agar selalu lengkap, sebagai konsekuensinya ada beberapa bahan pustaka yang tidak diminati atau kurang dibaca karena kurang sesuai dengan kebutuhan pengguna”. Taslimah Yusuf(1996: 71).

\section{Kerelevanan koleksi tercetak dalam memenuhi kepuasan pengguna pada Perpustakaan ITB}

Kerelevanan koleksi tercetak dalam memenuhi kepuasan pengguna dalam memenuhi kepuasan pengguna berkategori baik. Walaupun setiap perpustakaan berbeda visi dan misinya, perpustakaan yang berada dilingkungan perguruan tinggi harus menyediakan koleksi sesuai dengan kurikulum perguruan tinggi. Karena tujuan perpustakaan menyediakan koleksi perpustakaan menurut Yuyu dan Janti (2009: 15) "penyediaan koleksi perpustakaan perguruan tinggi merupakan tujuan untuk menunjang pelaksanaan program pendidikan, penga- 
jaran, penelitian, dan pengabdian kepada masyarakat"

Selain sesuai dengan kurikulum yang berlaku, Perpustakaan ITB juga diharapkan koleksinya mencakup seluruh mata kuliah yang ada di perguruan tinggi tersebut serta koleksi tercetak yang dapat memperkaya pengetahuan para penggunanya. Maka dari itu perpustakaan harus berorientasi pada kebutuhan pengguna yang relevan, agar koleksi yang ada di perpustakaan bisa dimanfaatkan dengan sebaik-baiknya.

"kegiatan pengembangan koleksi merupakan suatu kegiatan kerja perpustakaan yang bertugas menyediakan sumber informasi dan memberikan pelayanan informasi kepada pengguna sesuai dengan kebutuhan dan minat penggunanya". (Soeatminah, 2000: 66).

\section{Kemutakhiran koleksi tercetak dalam memenuhi kepuasan pengguna pada Perpustakaan ITB}

Kemutakhiran koleksi tercetak dalam memenuhi kepuasan pengguna berkategori baik hal ini karena hampir setengahnya Perpustakaan ITB telah menyediakan koleksi sesuai situasi dan kondisi saat ini, telah menyediakan koleksi tercetak yang mutakhir, telah menyediakan koleksi tercetak yang sesuai dengan kondisi dan situasi saat ini untuk mendapatkan informasi yang diutuhkaan dengan cepat dan mudah, dan setengahnya setuju Perpustakaan ITB telah menyediakan koleksi sesuai dengan perkembangan ilmu pengetahuan. Sulistyo-Basuki (1993: 132) menyataan bahwa “... pentingnya koleksi bahan pustaka yang mutakhir dan seimbang"

Dengan adanya koleksi yang mutakhir, kebutuhan pengguna akan terpenuhi. Apabila kebutuhan pengguna terpenuhi sesuai atau melebihi dengan harapan maka pengguna akan merasa puas. Puasnya pengguna akan menguntungkan bagi perpustakaan, karena dengan pengguna merasa puas, maka pengguna akan datang kembali ke perpustakaan untuk memanfaatkan koleksi tercetak yang tersedia di Peprustakaan ITB.

\section{Ketersediaan koleksi tercetak dalam memenuhi kepuasan pengguna pada perpustakaan ITB}

Ketersediaan koleksi tercetak dalam memenuhi kepuasan pengguna berkategori baik. Karena sebagian besar setuju informasi yang tersedia dalam koleksi tercetak telah sesuai dengan kebutuhan pengguna, sehingga pengguna akan datang kembali ke perpustakaan untuk memanfaatkannya kembali dan akan menyarankan kepada temantemanya tentang koleksi tercetak yang ada di perpustakaan dan hampir setengahnya setuju koleksi terectak yang tersedia di Perpustakaan ITB sesuai dengan harapan pengguna serta informasi yang tersedia di Perpustakaan ITB selalu didapat dengan mudah dan cepat sesuai dengan kebutuhannya.

Terpenuhi kebutuhan pengguna dengan cepat dan mudah akan menimbulkan perasaan puas, karena salah satu faktor kepuasan menurut Sulistyo (1992: 204) "kecepatan dalam menemukan atau mendapatkan informasi yang sesuai dengan kebutuhan pengguna".

Kebutuhan informasi pengguna perpustakaaan harus mampu dipenuhi oleh perpustkaaan, agar informasi yang disediakan dimanfaatkan oleh pengguna, maka perpustakaan harus memperhatikan kebutuhan pengguna dan tuntutan pengguna perpustakaan agar penggunanya merasa puas. Puas itu terjadi apabila apa yang diharapkan sesuai atau melebihi harapannya.

Berdasarkan pembahasan diatas dapat dikatakan ketersediaan koleksi tercetak Perpustakaan ITB sudah lengkap, relevan, dan mutakhir sehingga memberikan kepuasan kepada pengguna 
karena telah terpenuhi segala kebutuhannya.

\section{SIMPULAN}

Ketersediaan koleksi tercetak dalam memenuhi kepuasan pengguna Perpustakaan ITB berkategori baik hal ini karena pengguna setuju koleksi tercetak yang tersedia di Perpustakaan ITB sesuai dengan harapan pengguna, sebagian besar setuju informasi yang tersedia didalam koleksi tercetak selalu didapat dengan cepat dan mudah sesuai dengan kebutuhannya, pengguna akan datang lagi ke perpustakaan untuk memanfaatkan koleksi tercetak yang ada di Perpustakaan ITB, serta setengahnya setuju bahwa informasi yang disediakan Perpustakaan ITB sesuai dengan kebutuhan pengguna sehingga pengguna merasa puas atas ketersediaan koleksi di Perpustakaan ITB. Kelengkapan koleksi tercetak dalam memenuhi kepuasan pengguna di Perpustakaan ITB berkategori baik karena sebagian besar pengguna setuju Perpustakaan ITB menyediakan berbagai jenis koleksi tercetak seperti buku teks, buku referensi, majalah, jurnal, koran, skripsi, laporan penelitian dan koleksi tercetak yang langka. Perpustakaan ITB sebagian besar menyediakan koleksi buku-buku.

\section{DAFTAR PUSTAKA}

Departemen Pendidikan Nasional. (2008). Kamus Besar Bahasa Indonesia Pusat. Jakarta: PT Gramedia Pustaka Utama

Nawawi, H. H. (2001). Metode penelitian bidang sosial. Yogyakarta: Gadjah Mada University Press.

Soeatminah. (2000). Perpustakaan Kepustakawanan Dan Pustakwan. Yogyakarta: Kanisius. Sugiyono. (2012). Metode Penelitian
Kuantitatif, Kualitatif, dan $R \& D$. Bandung: ALFABETA.

Sulistyo-basuki . (1992). Teknik dan Jasa Dokumentasi. Jakarta: Gramedia Pustaka Utama. . (1993). Pengantar Ilmu Perpustakaan. Jakarta: PT Gramedia Pustaka Utama.

Supranto, J. (2011). Pengukuran Tingkat Kepuasan Pelanggan untuk Menaikkan Pangsa Pasar. Jakarta: Rineka Ciptao.

Tjipton, F. (2008). Strategi Pemasaran. Yogyakarta: CV. ANDI OFFSET.

UPT Perpustakaan Institut Teknologi Bandung. 2013. Laporan Statistik Bidang Layanan Periode Februari 2013. Bandung: UPT Perpustakaan ITB

Yulia, Y \& Janti, G. S. (2009). Pengembangan Koleksi. Jakarta: Universitas Terbuka.

Yusup, P.(1995). Pedoman Praktis Mencari Informasi. Bandung: PT Remaja Rosdakarya

Yusuf, T. (1996). Manajemen Perpustakaan Umum. Jakarta: Universitas Terbuka. 